\title{
Rancang Bangun Mesin Aqueous Cleaning Spray untuk Otomatisasi Proses Pencucian Produk High Speed Stamping di PT. ATMI IGI
}

\author{
(Design of Aqueous Cleaning Spray Machine to Automate The Washing Process of High \\ Speed Stamping Products at PT.ATMI IGI)
}

\author{
Hoedi Prasetyo ${ }^{a}$, Nurhadi Kusumo Yuwono ${ }^{b}$, Aloysius Avid Prabowo ${ }^{a}$, Michael Fernando Tema ${ }^{a}$, Valentino \\ Arlis Prasetya ${ }^{\text {a }}$, Yehuda Laurentinus ${ }^{a}$ \\ a 1 Program Studi Teknik Mekatronika, Politeknik ATMI Surakarta, \\ Jl. Adisucipto / Jl. Mojo No.1, Karangasem, Laweyan, Surakarta 57145 \\ hoedi.prasetyo@atmi.ac.id \\ ${ }^{b}$ Unit Machine Development Centre, PT. ATMI Solo, \\ Jl. Adisucipto / Jl. Mojo No.1, Karangasem, Laweyan, Surakarta 57145
}

\begin{abstract}
Abstrak
Produk hasil permesinan high speed stamping masih mengandung kotoran dan pelumas sehingga perlu dicuci terlebih dulu sebelum diproses lebih lanjut. Penelitian ini bertujuan melakukan otomatisasi proses pencucian produk high speed stamping di PT. ATMI IGI melalui rancang bangun mesin cuci berteknologi aqueous cleaning spray. Mesin memiliki dari 5 tahap proses yaitu Feeder, Pre-Wash, Wash, Rinse dan Spinning. Produk stamping dicuci secara otomatis melalui mekanisme konveyor, semprotan larutan deterjen, dan pengayak. Berdasar hasil uji coba, diketahui mesin memerlukan waktu rata-rata sebesar 34,5 detik untuk mencuci satu keranjang produk stamping. Mesin mampu mencuci 25 kali lebih cepat dibandingkan dengan proses pencucian secara manual. Penggunaan mesin berpotensi meningkatkan produktivitas dan efisiensi tenaga kerja. Mesin pada penelitian ini masih perlu dikembangkan untuk meningkatkan efisiensi proses pencucian dan masa pakai penggunaan cairan pembersih.
\end{abstract}

Kata kunci: high speed stamping; aqueous cleaning spray; otomatisasi; konveyor; inovasi proses

\begin{abstract}
Washing process in order to remove dirt and lubricants from the products before further processing is required in high speed stamping. This research aims to automate the high speed stamping washing process in PT. ATMI IGI by designing aqueous cleaning spray machine. The machine consists of five stages namely Feeder, Pre-Wash, Wash, Rinse and Spinning. The machine washes the stamping products automatically by mechanism of spraying cleaning solution, conveying, and sifting. Based on the trial results, the machine takes an average of 34.5 seconds to wash a basket of stamping products. The machine is able to wash 25 times faster than the manual wash. The machine potentially increase the productivity and labor efficiency. The machine being designed in this research still needs to be developed to improve the efficiency of the washing process and to prolong the cleaning solution lifetime.
\end{abstract}

Keywords: high speed stamping; aqueous cleaning spray; automation; process innovation

\section{Pendahuluan}

Produk stamping merupakan produk yang dihasilkan dari proses pencetakan sheet metal dengan menggunakan dies dan mesin penekan. Beberapa produk stamping dapat diproduksi secara masal melalui proses high speed stamping untuk menekan biaya produksi. Proses high speed stamping adalah proses stamping dengan kecepatan mencapai 2000 strokes per menit [1]. Menurut [2], seiring dengan pesatnya perkembangan industri otomotif dan perangkat elektronika, permintaan terhadap produk stamping juga semakin 
meningkat pesat. Salah satu tren yang harus diperhatikan oleh perusahaan manufaktur yang bergerak di bidang high speed stamping adalah kecepatan produksi.

PT. ATMI IGI adalah perusahaan domestik yang bergerak di bidang manufaktur. Perusahaan ini terletak di Kota Surakarta, Provinsi Jawa Tengah. Salah satu unit produksi yang dimiliki oleh perusahaan ini adalah high speed stamping (https://atmi-igi.co.id/) yang melayani kebutuhan produk stamping untuk beberapa produsen perangkat elektronika. Pihak manajemen perusahaan menyatakan bahwa produktivitas unit produksi high speed stamping masih rendah. Penyebab utama yang teridentifikasi adalah proses pencucian produk yang lambat karena masih dilakukan secara manual oleh tenaga manusia. Produk stamping masih mengandung pelumas dan kotoran setelah melewati proses permesinan sehingga perlu dicuci terlebih dulu sebelum lanjut ke proses berikutnya.

Menurut [3], ada dua teknologi utama untuk proses pencucian produk skala industri, yaitu teknologi solvent dan aqueous. Teknologi solvent memanfaatkan bahan kimia klorin untuk melarutkan kotoran. Teknologi ini memiliki resiko pencemaran lingkungan. Teknologi berikutnya adalah aqueous, yaitu teknologi pencucian menggunakan air sebagai bahan dasar utama sehingga dianggap lebih ramah lingkungan. Air dikombinasikan dengan bahan deterjen, pengaturan suhu, dan gaya mekanik tertentu untuk mengoptimalkan hasil pencucian [4]. Teknologi aqueous lebih diminati jika dibandingkan dengan teknologi solvent karena lebih efektif, ramah lingkungan, dan lebih mudah digunakan [5].

Proses pencucian produk stamping di PT. ATMI IGI memerlukan waktu yang relatif lama meskipun proses permesinan stamping berlangsung cepat. Kondisi tersebut menyebabkan bottleneck sehingga menurunkan produktivitas dan daya saing perusahaan. Menurut [6], diperlukan inovasi proses manufaktur untuk meningkatkan performa efisiensi dan kecepatan proses produksi. Inovasi ini juga diperlukan pada proses pencucian di unit produksi high speed stamping PT. ATMI IGI.

Terdapat beberapa literatur yang mengkaji inovasi proses pencucian pada produk stamping. Penelitian oleh [7] dan [8] merekomendasikan desain mesin pencuci produk stamping berbasis teknologi aqueous. Penelitian tersebut belum mengkaji sejauh mana pengaruh penggunaan mesin terhadap peningkatan produktivitas. Penelitian oleh [9] melakukan perbaikan proses pencucian produk stamping untuk industri otomotif melalui inovasi desain stasiun kerja. Penelitian ini menekankan pada perbaikan aspek ergonomi dan belum menunjukkan hasil perbaikan kecepatan proses. Penelitian oleh [12] merekomendasikan mesin cuci otomatis untuk produk stamping aluminium dengan metode full vacuum system. Mesin ini memiliki kapasitas pencucian 20 keranjang tiap jam dengan ukuran keranjang 4,8 meter $\times 3,2$ meter $\times 3$ meter. Mesin ini perlu biaya investasi tinggi serta kurang tepat digunakan untuk produk stamping yang berukuran kecil. Penelitian oleh [10] menyatakan bahwa penggunaan pelumas alternatif pada proses permesinan stamping dapat menurunkan biaya produksi sebesar $16 \%$. Penggunaan pelumas alternatif membantu optimalisasi proses pencucian namun belum berdampak signifikan pada peningkatan kecepatan produksi.

Perbaikan proses manufaktur yang berfokus pada peningkatan produktivitas memerlukan inovasi otomatisasi. Baik [11] dan [12] menyatakan bahwa untuk meningkatkan produktivitas, diperlukan mesin cuci otomatis yang diintegrasikan pada proses produksi. Pendapat ini juga didukung oleh studi yang dilakukan [13] yang menyatakan bahwa melalui otomatisasi proses pencucian, tingkat produktivitas yang lebih tinggi dapat dicapai dan sumber daya manusia yang digantikan dapat dialokasikan ke bagian produksi lain yang lebih memerlukan ketelitian dan waktu. Berdasar hasil kajian literatur, dapat disimpulkan bahwa usaha perbaikan proses pencucian yang memiliki tujuan akhir peningkatan produktivitas memerlukan inovasi otomatisasi.

Inovasi proses manufaktur tidak harus dilakukan secara radikal, namun dapat dilakukan dengan metode inovasi lokal, yaitu dengan menerapkan solusi yang telah ada di dunia industri namun relatif masih baru bagi perusahaan [6]. Metode inovasi ini sesuai untuk diterapkan pada perusahaan manufaktur skala kecil dan menengah yang memiliki keterbatasan pendanaan untuk kegiatan riset dan pengembangan. Penelitian pada makalah ini bertujuan melakukan otomatisasi proses pencucian produk high speed stamping di PT. ATMI IGI sehingga produktivitasnya dapat ditingkatkan. 


\section{MetOde}

Metode yang digunakan pada penelitian ini mengadopsi metode generic product development process yang dikembangkan oleh [14]. Penelitian ini menggunakan lima dari enam tahap generic product development yaitu tahap perencanaan, tahap pengembangan konsep, tahap perancangan tingkat sistem, tahap perancangan detail, dan tahap pengujian.

Tahap perencanaan terdiri dari identifikasi peluang, penyusunan tujuan, penentuan batasan, serta penentuan platform teknologi mesin yang akan digunakan. Tahap ini secara garis besar telah dijelaskan pada sub judul pendahuluan. Tahap pengembangan konsep adalah tahap untuk menentukan konsep mesin meliputi bentuk, fungsi, fitur dan solusi teknologi yang diperlukan. Tahap perancangan tingkat sistem adalah tahap untuk menghasilkan rancangan arsitektur mesin, sub sistem penyusun, dan diagram aliran proses. Tahap perancangan detail terdiri dari penentuan spesifikasi teknis komponen-komponen yang diperlukan serta rancangan panel kendali dan kelistrikan. Tahap pengujian adalah tahap untuk menguji rancangan mesin meliputi fungsi, performa kecepatan, dan kualitas hasil proses mesin. Kualitas hasil pencucian pada penelitian ini diperiksa secara kualitatif dan divalidasi oleh operator yang telah berpengalaman.

\section{Hasil dan Pembahasan}

Berdasar hasil observasi, diketahui bahwa proses high speed stamping di PT. ATMI IGI menggunakan mesin Haulick Roos tipe RSH 500-1250 dengan kapasitas 50 ton dan kecepatan maksimal 1000 strokes per menit. Rata -rata kecepatan produksi mesin aktual sebesar 135 strokes per menit. Bahan mentah berupa gulungan sheet metal kuningan dengan lebar kurang lebih $5 \mathrm{~cm}$. Pergerakan bahan mentah ke mesin dibantu oleh mekanisme roller-feeding seperti yang ditunjukkan Gambar 3.1(a). Hasil proses stamping langsung ditampung ke dalam keranjang seperti yang ditunjukkan Gambar 3.1(b). Operator mengganti keranjang yang sudah terisi setengah penuh dengan keranjang lain yang kosong. Keranjang berisi produk stamping kemudian dibawa ke area pencucian.

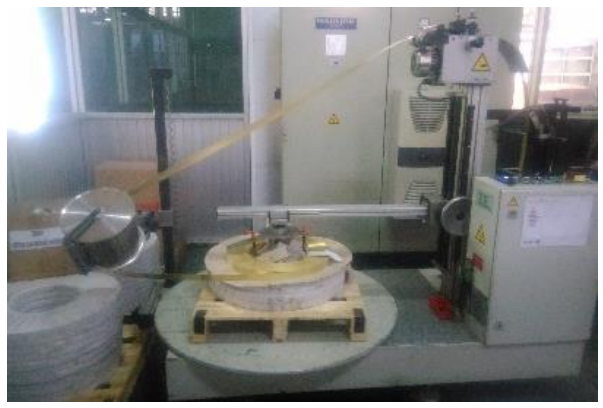

(a)

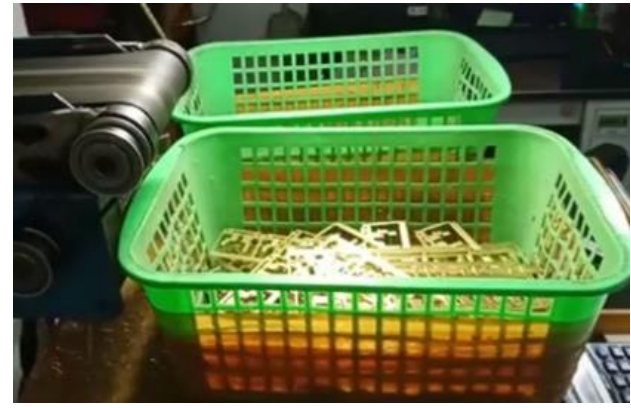

(b)

Gambar 3.1 Proses produksi high speed stamping: (a) gulungan bahan mentah, (b) keranjang penampung produk stamping

Sesuai referensi oleh [3], proses pencucian produk stamping di PT. ATMI IGI menerapkan teknologi aqueous yang terdiri dari tiga tahap, yaitu wash, rinse, dan dry. Tahap wash adalah tahap pembersihan produk dari pelumas dan kotoran dengan larutan air dan detergen. Tahap rinse adalah tahap membersihkan produk dari deterjen menggunakan air bersih. Tahap dry adalah tahap pengeringan produk. Tahap dry dilakukan dengan cara menyemprotkan udara kering dari kompresor. Tiap tahap pencucian dilakukan oleh satu orang pekerja sehingga total proses pencucian memerlukan tiga orang pekerja seperti yang ditunjukkan pada Gambar 3.2. Produk yang telah selesai dicuci kemudian masuk ke proses quality control. Setelah melewati proses quality control, produk dikemas dan dikirim kepada pelanggan. 


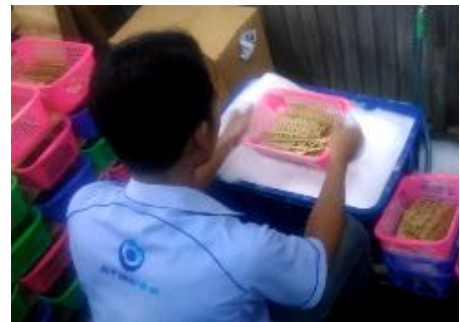

(a)

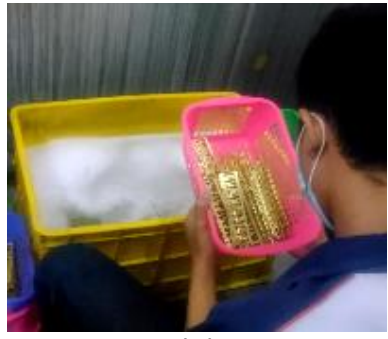

(b)

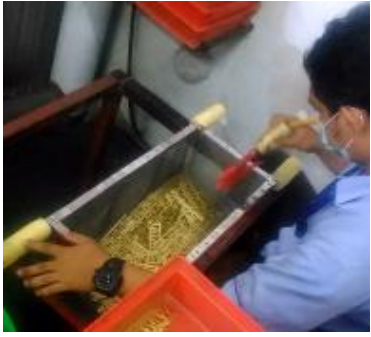

(c)

Gambar 3.2 Proses pencucian secara manual: (a) wash, (b) rinse, (c) dry

Konsep mesin yang dirancang pada penelitian ini memperhatikan fitur yang diminta oleh pihak manajemen. Rancangan fitur mempertimbangkan batasan dimensi ruang produksi, ketersediaan dana, serta kemampuan teknologi. Daftar rancangan fitur dan solusi teknologi dapat dilihat pada Tabel 3.1 Produk high speed stamping memiliki karakteristik produk yang berukuran relatif kecil dengan tipe produksi kontinyu. Menurut [15], tipe teknologi mesin cuci yang tepat untuk produk stamping adalah teknologi konveyor dengan metode aqueous cleaning spray. Metode tersebut bekerja dengan cara menyemprotkan cairan dengan suhu dan tekanan tertentu melalui nozzle pada produk yang dicuci $[17,18]$.

Tabel 3.1 Fitur mesin dan solusi teknologi

\begin{tabular}{|c|c|c|}
\hline No & Fitur & Solusi Teknologi \\
\hline 1 & $\begin{array}{l}\text { Produk berjalan melewati proses } \\
\text { pencucian secara otomatis }\end{array}$ & $\begin{array}{l}\text { Mekanik: konveyor polimer, guide rail, } \\
\text { sistem transmisi sabuk. } \\
\text { Elektrik: motor induksi dengan kendali } \\
\text { inverter }\end{array}$ \\
\hline 2 & $\begin{array}{l}\text { Jumlah produk stamping per } \\
\text { keranjang seragam }\end{array}$ & $\begin{array}{l}\text { Elektrik: photosensor, counter digital, motor } \\
\text { brake }\end{array}$ \\
\hline 3 & Pencucian dengan penyemprotan & $\begin{array}{l}\text { Mekanik: pipa, nozzle, water barrier. } \\
\text { Elektrik: motor pompa }\end{array}$ \\
\hline 4 & Ada mekanisme pengayak & $\begin{array}{l}\text { Mekanik: poros bubungan (camshaft), } \\
\text { sistem transmisi sabuk. } \\
\text { Elektrik: motor induksi dengan kendali } \\
\text { inverter }\end{array}$ \\
\hline 5 & $\begin{array}{l}\text { Air dan cairan pembersih dapat } \\
\text { didaur ulang }\end{array}$ & $\begin{array}{l}\text { Mekanik: bak penampung dan daur ulang } \\
\text { limbah cairan. } \\
\text { Elektrik: pompa sentrifugal }\end{array}$ \\
\hline 6 & Hanya perlu satu orang operator & $\begin{array}{l}\text { Desain panel listrik dan kendali dipasang } \\
\text { pada satu titik lokasi }\end{array}$ \\
\hline 7 & Pengeringan otomatis & $\begin{array}{l}\text { Mekanik: tabung dan kerangka spin dryer. } \\
\text { Elektrik: motor induksi dengan kendali } \\
\text { inverter, kontaktor timer }\end{array}$ \\
\hline
\end{tabular}

Rancangan mesin terdiri dari lima sub sistem yaitu unit Feeder, unit Pre-Wash, unit Wash, unit Rinse, dan unit Spin Dryer. Aliran proses mesin dapat dilihat pada Gambar 3.3. Produk yang dihasilkan dari proses stamping ditampung ke dalam keranjang di unit Feeder. Produk yang masuk ke dalam keranjang dideteksi oleh photosensor dan dihitung oleh counter digital. Proses ini untuk memastikan tiap keranjang memiliki jumlah produk yang seragam. Keranjang kemudian bergerak melalui konveyor menuju ke unit Pre-Wash. Produk stamping kemudian disemprot dengan air bersih untuk menghilangkan kotoran berupa debu atau partikel lain. Keranjang selanjutnya bergerak melalui konveyor menuju ke unit Wash. 
Unit Wash berfungsi membersihkan produk dari pelumas dengan cara menyemprotkan campuran air dan deterjen.

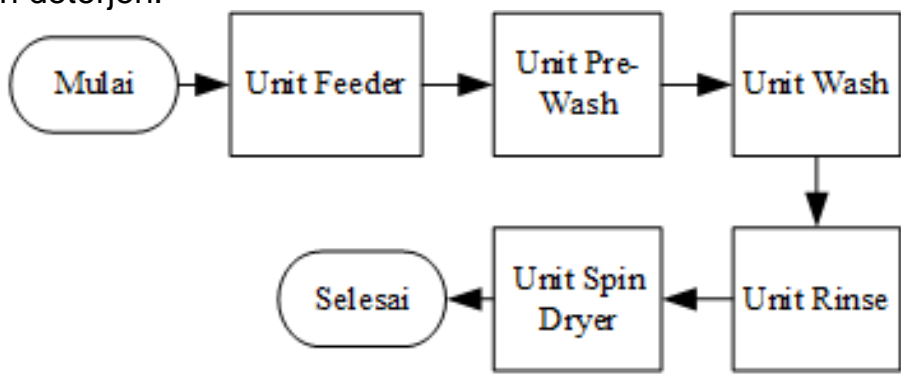

Gambar 3.3. Aliran proses mesin

Keranjang selanjutnya bergerak menuju ke unit Rinse untuk disemprot kembali dengan air bersih. Unit Rinse berfungsi membersihkan produk dari sisa deterjen yang masih menempel. Keranjang kemudian bergerak ke area resting. Operator akan mengambil keranjang dan menuangkan produk stamping ke dalam tabung unit Spin Dryer. Unit Spin Dryer berfungsi mengeringkan produk dengan prinsip putaran sentrifugal seperti yang dikembangkan oleh [16]. Bagian pengering dirancang terpisah dari mesin cuci karena keterbatasan area dan alasan biaya. Pengoperasian unit Spin Dryer dilakukan oleh operator. Durasi pengeringan dapat diatur dengan kontaktor timer. Keranjang yang kosong kemudian dikembalikan lagi ke unit Feeder oleh operator.

Rancangan tiga dimensi mesin dapat dilihat pada Gambar 3.4. Mesin memiliki ukuran panjang 4,4 meter, lebar 2,4 meter, dan tinggi 1,2 meter. Kerangka mesin yang berpotensi terkena air dibuat dari bahan stainless steel sedangkan bagian yang lain dibuat dari bahan mild steel. Mesin terdiri dari dua konveyor. Konveyor pertama digunakan untuk unit Feeder. Konveyor kedua digunakan untuk unit Pre-Wash sampai dengan unit Rinse. Seluruh sabuk konveyor menggunakan bahan polimer agar tahan air. Tiap konveyor digerakkan oleh motor listrik yang dihubungkan dengan sistem transmisi sabuk.

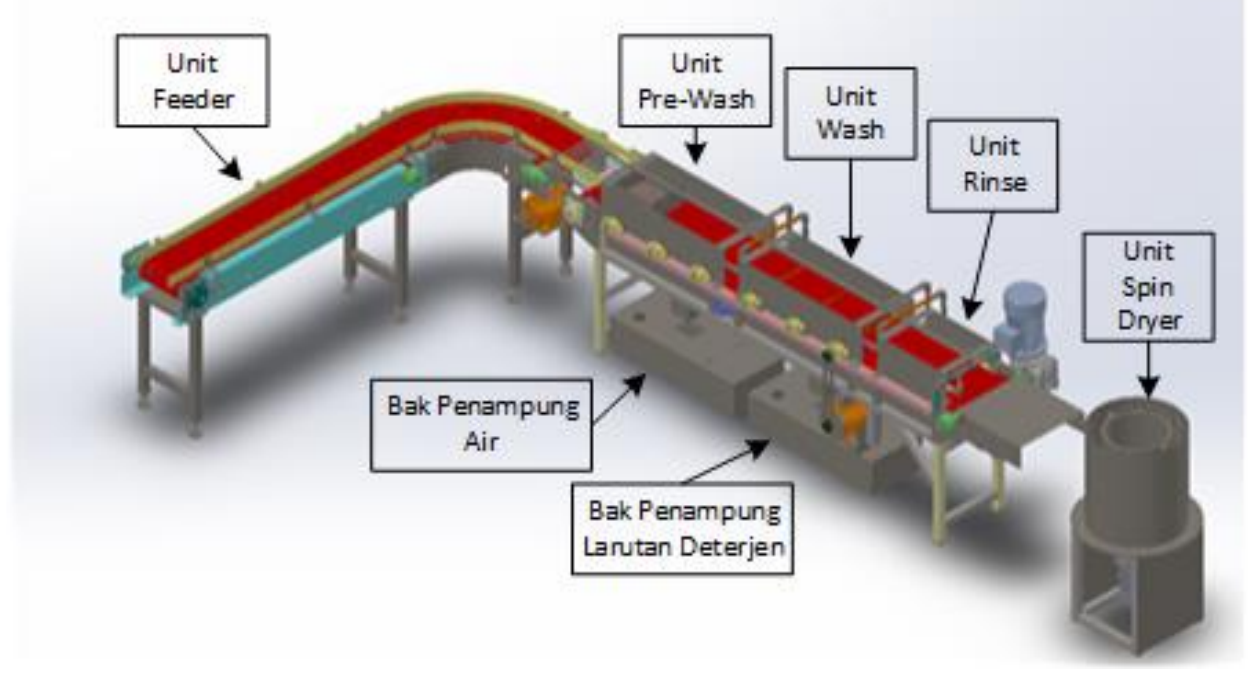

Gambar 3.4 Rancangan mesin cuci otomatis

Konveyor pertama digerakkan oleh motor brake. Tipe motor ini dipilih agar konveyor dapat dengan mudah dihentikan dan dijalankan kembali saat proses pengisian produk ke dalam keranjang. Konveyor pertama dirancang berbentuk radius untuk efisiensi penggunaan area. Tipe sabuk konveyor yang digunakan adalah M2540 Radius Flush Grid [17].

Konveyor kedua menggunakan tipe motor induksi yang dihubungkan dengan inverter sehingga kecepatannya dapat diatur. Tipe sabuk konveyor yang digunakan adalah M1234 
Nub Top Flush Grid [18]. Konveyor kedua memiliki mekanisme pengayak vertikal yang bertujuan mengoptimalkan proses pencucian agar lebih merata. Mekanisme pengayak memanfaatkan prinsip poros bubungan (camshaft) yang dihubungkan dengan motor induksi dan inverter melalui sistem transmisi sabuk.

Terdapat dua bak yang terletak di bawah mesin untuk menampung air bersih dan larutan deterjen. Bak ini berfungsi untuk menampung air dan mendaur ulang cairan limbah hasil proses pencucian. Proses daur ulang bertujuan untuk menghemat penggunaan air dan deterjen. Mesin yang dirancang menggunakan tiga buah pompa sentrifugal. Dua pompa dipasang untuk memompa air dari bak penampung air menuju ke pipa dan nozzle pada unit Pre-Wash dan unit Rinse. Satu pompa dipasang untuk memompa cairan dari bak penampung larutan deterjen menuju ke unit Wash. Tipe pompa yang digunakan adalah Grundfos NS 13-18. Hasil realisasi rancangan mekanik mesin cuci dapat dilihat pada Gambar 3.5(a).

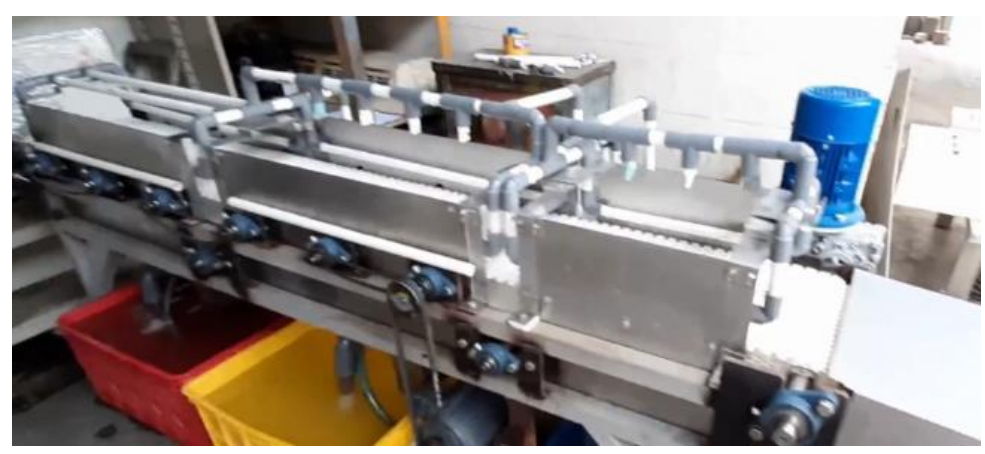

(a)

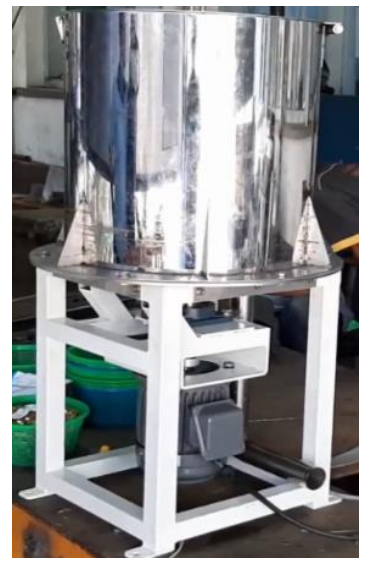

(b)

Gambar 3.5 Realisasi rancangan: (a) unit Pre-Wash, Wash, dan Rinse, (b) unit Spin Dryer

Unit Spin Dryer memiliki ukuran diameter 0,5 meter dan tinggi 1,5 meter. Unit ini terdiri dari tangki dan kerangka kaki. Bagian tangki terdiri dari tabung berpori yang dapat berputar untuk memisahkan produk dari air, saluran pembuangan air, serta tabung penutup tangki. Bagian kerangka kaki digunakan untuk pemasangan motor listrik induksi yang dihubungkan dengan inverter. Unit ini memiliki kapasitas pengeringan sebesar 10 kilogram. Hasil realisasi rancangan mekanik unit Spin Dryer dapat dilihat pada Gambar 3.5(b).

Bagian kelistrikan mesin yang dirancang memiliki spesifikasi daya 4 kilowatt dan sambungan tegangan 3 fasa 380 Volt. Kelistrikan mesin terbagi menjadi 2 panel listrik. Panel pertama untuk kelistrikan unit Feeder sampai unit Rinse. Panel kedua untuk kelistrikan unit Spin Dryer. Panel listrik mesin secara umum terdiri dari komponen relai, kontaktor, pengaman arus berlebih, inverter, lampu indikator, sakelar, dan tombol. Desain panel listrik mesin dapat dilihat pada Gambar 3.6. 


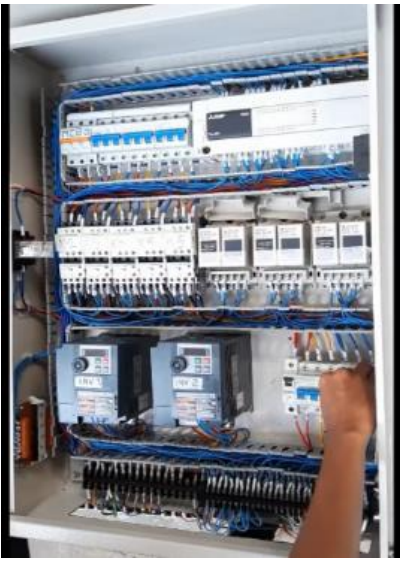

(a)

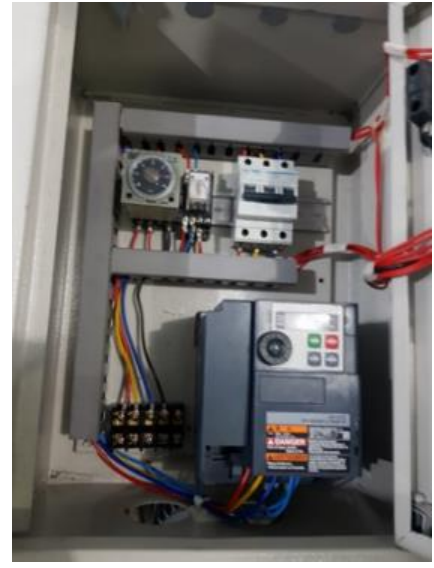

(b)

Gambar 3.6 Panel listrik: (a) unit Feeder-Rinse, (b) unit Spin Dryer

Hasil uji coba menunjukkan mesin dapat beroperasi dengan optimal ketika nilai frekuensi inverter motor konveyor kedua diatur sebesar $35,7 \mathrm{~Hz}$ dan frekuensi inverter motor pengayak diatur sebesar $30,7 \mathrm{~Hz}$. Pengaturan dengan nilai frekuensi tersebut menghasilkan kualitas hasil pencucian sama baiknya dengan hasil pencucian secara manual. Pencatatan durasi waktu proses pencucian pada tahap uji coba dilakukan mulai saat keranjang masuk ke unit Feeder sampai saat keranjang keluar dari unit Rinse. Pencatatan durasi waktu pengeringan belum dilakukan karena proses realisasi unit Spin Dryer masih belum selesai. Hasil pencatatan waktu kemudian dibandingkan dengan hasil pencatatan waktu proses pencucian secara manual.

Berdasar hasil pengamatan, proses pencucian secara manual mulai dari tahap wash sampai rinse memerlukan waktu rata-rata sebesar 894 detik atau sekitar 15 menit untuk satu keranjang produk stamping. Durasi waktu tersebut didominasi oleh waktu tunggu dari tahap wash menuju rinse. Tahap rinse memerlukan waktu rata-rata dua kali lipat lebih lama dibandingkan dengan tahap wash. Hal ini mengakibatkan terjadinya bottleneck. Berdasar hasil pencatatan waktu pada uji coba mesin, proses pencucian otomatis mulai dari unit Feeder sampai keluar dari unit Rinse memerlukan waktu rata-rata sebesar 34,5 detik. Berdasar hasil tersebut, dapat dihitung peningkatan kecepatan proses pencucian yaitu sebesar 25 kali dari kecepatan pencucian secara manual. Perbandingan antara waktu proses pencucian secara manual dengan waktu proses pencucian secara otomatis dapat dilihat pada Tabel 3 ..

Tabel 3.2 Hasil perbandingan durasi waktu pencucian

\begin{tabular}{ccccc}
\hline No & $\begin{array}{c}\text { Metode } \\
\text { Pencucian }\end{array}$ & $\begin{array}{c}\text { Jumlah Sampel } \\
\text { (keranjang) }\end{array}$ & $\begin{array}{c}\text { Rata-rata waktu } \\
\text { proses (detik) }\end{array}$ & $\begin{array}{c}\text { Peningkatan } \\
\text { Kecepatan Proses }\end{array}$ \\
\hline 1 & Manual & 30 & 894 & 25,88 kali \\
2 & Otomatis & 30 & 34,5 & \\
\hline
\end{tabular}

Otomatisasi proses pencucian pada penelitian ini menghasilkan dampak perbaikan yang sangat signifikan. Kecepatan proses pencucian dapat meningkat beberapa kali lipat. Kondisi ini berpotensi meningkatkan produktivitas unit produksi high speed stamping PT. ATMI IGI dengan asumsi pada tahap produksi yang lain tidak terjadi bottleneck. Keuntungan lain yang didapat adalah adanya efisiensi jumlah tenaga kerja. Hal ini juga dinyatakan oleh [14]. Mesin cuci otomatis yang dirancang pada penelitian ini hanya perlu satu operator, sehingga dua operator yang tersisa dapat dialihfungsikan untuk membantu pekerjaan lain.

Rancangan mesin cuci otomatis pada penelitian ini masih memiliki beberapa kekurangan. Proses pencucian belum menggunakan pemanas, hanya mengandalkan 
tekanan semprotan cairan dan deterjen. Menurut [19], penggunaan pemanas air diperlukan untuk meningkatkan efisiensi proses pencucian. Masa pakai larutan deterjen hasil daur ulang limbah masih pendek karena belum menggunakan mekanisme penyaringan kotoran. Diperlukan 50 liter air dan 50 mililiter cairan deterjen untuk mencuci 10 keranjang produk stamping. Masa pakai larutan deterjen dapat diperpanjang menggunakan teknologi microfilter dan oil skimmer seperti yang dilakukan oleh [4, 23].

\section{KesimpULAN}

Penelitian ini berhasil mengembangkan mesin cuci otomatis aqueous spray cleaning untuk unit produksi high speed stamping di PT. ATMI IGI. Mesin cuci yang dikembangkan bertujuan menggantikan proses pencucian yang selama ini dilakukan secara manual. Mesin dirancang menggunakan metode generic product development process. Hasil uji coba menunjukkan proses pencucian dengan mesin cuci otomatis jauh lebih cepat jika dibandingkan dengan pencucian secara manual. Hasil tersebut berpotensi memberikan keuntungan bagi perusahaan berupa peningkatan produktivitas dan efisiensi tenaga kerja. Efisiensi proses pencucian dan masa pakai penggunaan larutan deterjen pada penelitian ini masih perlu diperbaiki. Penelitian lanjutan masih diperlukan untuk mengkaji secara empiris berapa nilai peningkatan produktivitas dari hasil integrasi mesin cuci otomatis ke lantai produksi.

\section{Daftar Pustaka}

[1] Altan, T., \& Tekkaya, A. E. (Eds.). Sheet metal forming: processes and applications. Ohio: ASM international. 2012: 10.

[2] Xiao, M. H., Yu, L. B., Li, G. H., \& Liang, W. J. Development of High Speed Precision Press and its Development Trends. Key Engineering Materials. 2016; 693: 89-92.

[3] Durkee, J. Management of industrial cleaning technology and processes. Elsevier. 2006: 1-41.

[4] Durkee, J. The second cleaning process: The oil skimmer-part I. Metal Finishing. 2008; 106(6): 86-88.

[5] Tulinski, E.H. Aqueous washing systems. Metal Finishing. 2007; 105(10): 129-138.

[6] Yamamoto, Y., Bellgran, M. Four types of manufacturing process innovation and their managerial concerns. Procedia CIRP. 2013; 7: 479-484.

[7] Smith, R.W. Successful aqueous washing. SME Technical Paper. 1994: 94-126

[8] Grewal, M.S. Switch to Aqueous Technology Gives Gillette Edge in Blade Manufacturing. Precision Cleaning - The Magazine of Critical Cleaning Technology. 1995: 15-26.

[9] Halim, I., Omar, A. R., \& Saad, N. H. Ergonomic assessment to identify occupational risk factor in metal stamping industry. NAME. 2005; 5: 2005.

[10] Landi, D., Germani, M., Mandolini, M., Marconi, M., \& Favi, C. Environmental and Economic Evaluation of the Sheet Metal Stamping Process Using Alternative Lubricants. International Design Engineering Technical Conferences and Computers and Information in Engineering Conference. California. 2019: V004T05A027.

[11] Mitschele, M. Fully Automatic Cleaning Line with Clean Room Connection. IST International Surface Technology. 2014; 7(2): 24-25.

[12] Klabuschnig, J. Aqueous cleaning process with solvent-based corrosion protection. IST International Surface Technology. 2017; 10(3): 46-47.

[13] Sundin, E., Elo, K., \& Lee, H. M. (2012). Design for automatic end-of-life processes. Assembly Automation. 2012; 32(4): 389-398

[14] Eppinger, S., Ulrich, K. Product design and development. McGraw-Hill Higher Education. 2015: 15.

[15] Durkee, J. Cleaning times: Aqueous cleaning machines: How they work, and why-part II. Metal Finishing. 2009; 107(4): 65-66.

[16] Reeder, C. H. Centrifugal Dryer. U.S. Patent No. 3,391,469. 1968.

[17] Habasit. Product Data Sheet: Habasit LINK M2540 Radius Flush Grid. 2019

[18] Habasit. Product Data Sheet: M1234 Nub Top Flush Grid. 2018

[19] Kim, H. S., \& Kweon, J. H. Cleaning of lubricating products from machinery parts using subcritical water. KSCE Journal of Civil Engineering. 2010; 14(1): 1-6. 